\title{
Pediatric head traumas: A different perspective
}

\author{
Soner Yaşar, M.D., ¿ Alparslan Kırık, M.D., @ Mehmet Ozan Durmaz, M.D.
}

Department of Neurosurgery, University of Health Sciences, Gülhane Faculty of Medicine, Ankara-Turkey

\begin{abstract}
BACKGROUND: We aim to present our series on pediatric head traumas and discuss our results with the current literature.

METHODS: The data of children who underwent treatment for head trauma in our department between 2010 and 2019 were retrospectively reviewed. Their clinical condition at admission, radiological findings, treatment methods and outcomes were analyzed.

RESULTS: Ninety children underwent treatment for head trauma, 60 of them were male and 30 were female. The mean age was 6.6 years. Linear skull fracture was seen 55 patients, while epidural hematoma in 15 patients. Twenty patients underwent surgical treatment, while 70 patients underwent conservative treatment. No patient died in our series, three patients underwent rehabilitation due to neurological deficits after discharge.
\end{abstract}

CONCLUSION: Children were more prone to head trauma, but their mortality was less than the adults. Conservative treatment should be the first goal, but surgical management should be reserved for children with significant hematoma and declining neurological conditions.

Keywords: Child; head trauma; outcome; surgery.

\section{INTRODUCTION}

Head trauma is an important health issue in the population. Adults and children may be affected by head traumas. These injuries may cause different clinical and surgical conditions, ranging from mild to severe head traumas. ${ }^{[1]}$ Although most of childhood head injuries are minor, many children die or develop permanent disabilities each year from head trauma. ${ }^{[2-4]}$

The most common causes of head injuries in children are motor vehicle accidents, falls, assaults, bicycle accidents and sport traumas. Most serious head injuries in infants younger than one year old are related to child abuse or abusive head traumas. ${ }^{[5-7]}$

Head injuries may cause many symptoms, depending on the type of injury, its severity and its location on the head. The child's neurological symptoms may include: loss of consciousness, headache, dizziness, nausea and vomiting, difficulty walking, slurred speech, amnesia, seizure and hemiparesis or hemiplegia. . $^{[1,2,4,8,9]}$
Mild head traumas in children usually do not require any treatment other than close monitoring for at least 48 hours. Careful monitoring is very important in children with concussion and the child may need bed rest and to stay out of sports for a limited time period. In children with serious head traumas, management protocol depends on the type and severity of head injury, as well as on the location. Sometimes, the patient needs medical treatment in an intensive care unit, including antiedema, anticonvulsives, analgesics, and antibiotics if required. ${ }^{[1,4,10]}$ The aim of medical treatment is to decrease the intracranial pressure, maintain the blood pressure and prevent seizures. Surgery may need for an epidural or subdural hematoma, or a depressed skull fracture, brain hemorrhage or contusion.

The present study aims to present our series of 90 children who underwent treatment for head trauma. Their clinical presentation and treatment strategies are summarized and discussed with the current literature.

Cite this article as: Yaşar S, Kırık A, Durmaz MO. Pediatric head traumas: A different perspective. Ulus Travma Acil Cerrahi Derg 2020;26:765-768.

Address for correspondence: Soner Yaşar, M.D.

Sağlık Bilimleri Üniversitesi, Gülhane Tıp Fakültesi, Beyin ve Sinir Cerrahisi Anabilim Dalı, Ankara, Turkey

Tel: +90 312 - 3045344 E-mail: dr.soneryasar@gmail.com

Ulus Travma Acil Cerrahi Derg 2020;26(5):765-768 DOI: 10.14744/tjtes.2020.24287 Submitted: 28.09.2019 Accepted: 19.01.2020 Online: 09.09.2020

Copyright 2020 Turkish Association of Trauma and Emergency Surgery 


\section{MATERIALS AND METHODS}

Ethical approval was obtained for this retrospective study. The data of pediatric patients (0-18 years) who were admitted and treated for head trauma in our department between 2010 and 2019 were retrospectively reviewed. Demographic, radiological, clinical and surgical features of the patients were analyzed. Computed tomography (CT) was used in all patients for diagnosis. Magnetic resonance imaging (MRI) was preferred in selected cases with diffuse axonal injury. Surgical treatment was administered in patients with acute epidural/ subdural hematoma causing intracranial hypertension, depressed skull fractures and open fractures. Other cases were treated conservatively.

\section{RESULTS}

Ninety patients were treated in a 10 year period. Thirty patients were female and 60 were male. Mean age was 6.6 years (range 0 and 18 years). The causes of trauma were falls, car accidents, and sport injuries. The most common diagnosis was linear fracture in 55 cases (Fig. I) and epidural hematoma in 15 patients (Fig. 2). Subdural hematoma was observed in six children and three of them underwent surgical treatment. Others were treated conservatively (Fig. 3). Depression fracture was observed in five cases (Fig. 4). After the diagnosis, surgical treatment was administered in 20 children, while conservative management was applied in 70 cases. There was no mortality in our series, while three patients were transferred to the rehabilitation unit for neurological deficits. Other patients were discharged without complication or deficit. The mean follow-up was 17 months (ranged 3-39 months).

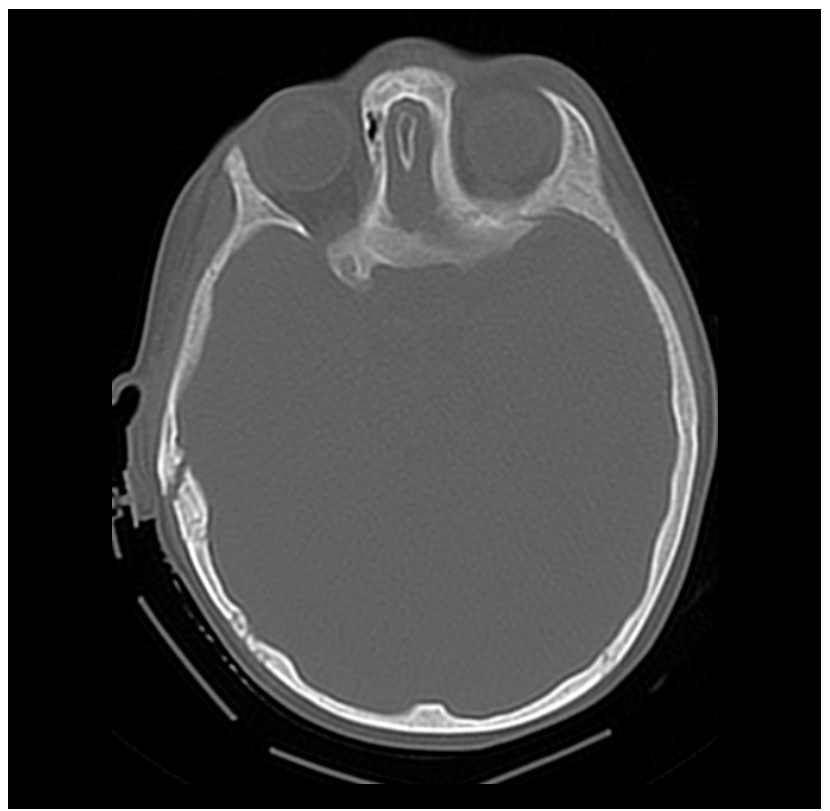

Figure 1. Axial CT scan of a 2-years old male child with the left temporal linear fracture.

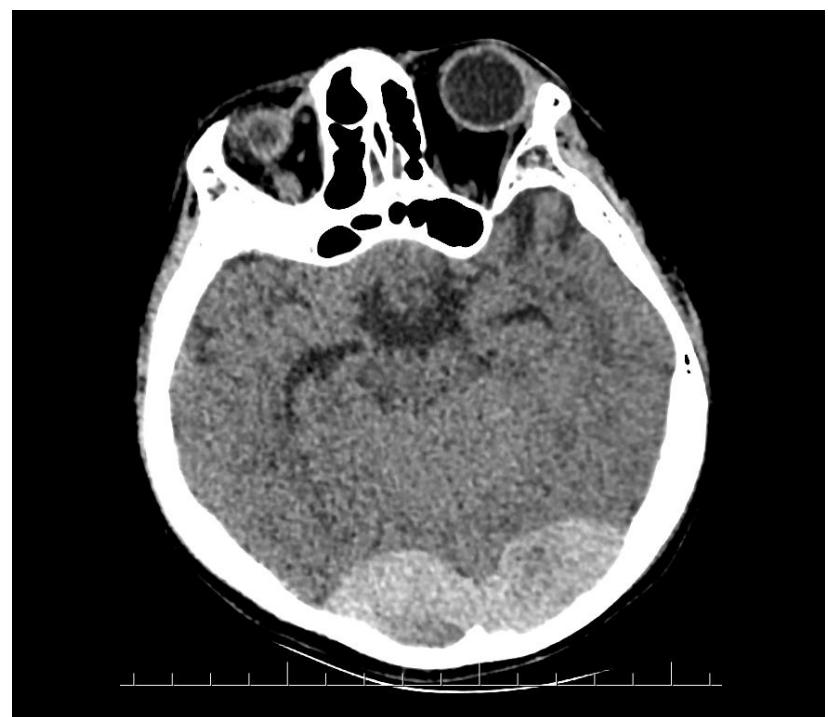

Figure 2. Axial CT scan of a 12-years old male child with occipital fracture and acute epidural hematoma. He underwent emergent evacuation of the epidural hematoma.
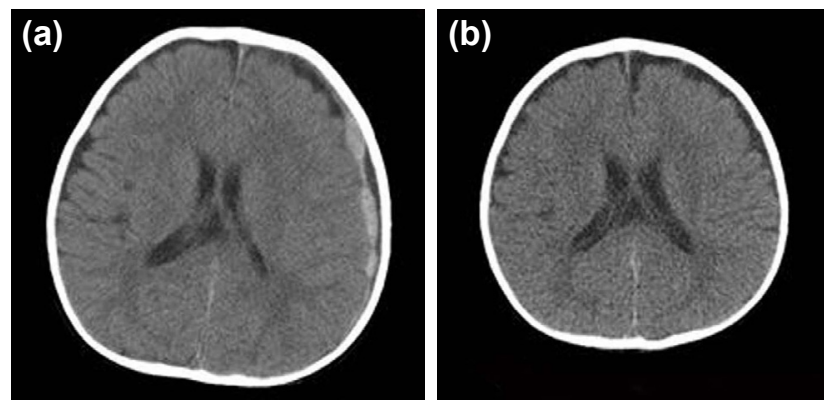

Figure 3. Axial CT scan of a 3-years-old child shows left parietal acute subdural hematoma (a). Three days later, subdural hematoma was spontaneously cleaned with the CSF (b).



Figure 4. 3-D CT scan of a child with left frontal depression fracture reaching to the orbital roof. 


\section{DISCUSSION}

We presented the results of 90 children who admitted to our department with head trauma. Most of them had skull fractures but surgical treatment was applied only in 70 patients. Conservative treatment was the most preferred method for children in our series. None of them died after treatment.

Head trauma occurs commonly in childhood. Most children with head trauma are young and male. In addition, head trauma in children is usually minor and not associated with brain injury or long-term squeal. However, a small number of children who appear to be at low risk after minor head trauma may have a clinically important brain injury. In the USA, children younger than 14 years of age, traumatic brain injury (TBI) accounts for approximately 500,000 emergency department visits, 37,000 hospitalizations and over 2000 deaths annually. ${ }^{\left[{ }^{l}\right]}$ In developed countries, TBI is the most common cause of death and disability in childhood. ${ }^{[12]}$

In children, the major challenge for assessment of a mild head trauma is to determine those young children and infants who need a neuroradiological study. Today, CT scan is highly sensitive to identify an intracranial lesion that may require acute intervention. ${ }^{[7,13,14]} \mathrm{MRI}$ is not useful in the initial management of head trauma in children because of the longer duration of MRI than CT scan and it requires full cooperation of child. MRI can also miss out skull fractures which can be easily detected by CT scan. In our series, we used CT scans in all cases, but MRI was mainly preferred to detect diffuse axonal injury.

Pediatric head trauma may be mild, moderate or severe. Mild trauma is generally associated with minor symptoms, such as a short loss of consciousness, disorientation or vomiting. ${ }^{\left[{ }^{[1]}\right.}$ They usually have GCS scores of 13 to 15 which measured approximately 30 minutes after the injury. In comparison, patients with moderate trauma generally have an initial GCS scores between 9 and 12 , whereas patients with severe trauma have GCS scores $\leq 8$. Concussion can be defined as trauma-induced brain dysfunction without any structural injury on standard neuroradiology. ${ }^{[4]}$ Brain injury may occur following a minor head trauma because rotational acceleration-deceleration of the head generates shearing forces that cause mechanical disruption of nerve fibers, resulting in diffuse axonal injury. ${ }^{[1,6,13]}$ This condition can only be detected by MRI scan.

Head trauma may produce hematoma in the child's brain. These hematomas are epidural, subdural or intraparenchymal. Epidural hematomas typically arise from a direct blow resulting in a linear fracture that cross the branches of middle meningeal artery or dural venous sinuses, but may also occur without an associated fracture in a significant number of children. Early diagnosis and treatment is crucial for epidural hematoma. ${ }^{[15-17]}$ Binder et al. ${ }^{[8]}$ reviewed 41 pediatric patients with traumatic epidural hematoma and they concluded that age, severity of trauma and neurological status are the main factors affecting the outcome of acute epidural hematoma in children. In our series, linear skull fracture was detected in 55 patients, while epidural hematoma in 15 patients, 13 of them underwent surgical treatment. None of them died after surgery. Gekat et al. ${ }^{[17]}$ reviewed 56 cases of epidural and 38 cases of subdural hemorrhage and they showed that subdural hematoma is more common in young children and mostly the result of a suspected abuse in children under two years of age. Subdural hematomas may also be seen in children with head trauma. Sometimes, abusive traumas may present with subdural hematoma or hygroma. Subdural hematomas usually require surgery, but rapid spontaneous resolution may also occur. ${ }^{[18,19]}$ In our series, subdural hematoma is less frequent and observed in six patients. There was no suspicion of abuse in our cases. Three of them underwent early surgical evacuation. One patient with acute subdural hematoma was improved within three days with conservative treatment.

Abusive head trauma, also known as a shaken baby syndrome, is one of the most common subtypes of nonaccidental trau$\mathrm{ma}$ and is a leading cause of traumatic brain injury in young children ${ }^{[5]}$ Understanding the common patterns of abusive head injury can help increase diagnostic accuracy both by increasing recognition of injuries with high specificity for AHT and by avoiding unwarranted concern in patients with concordant injury patterns and clinical history. ${ }^{[20]}$ In our series, we not encountered any abusive head trauma.

Astrand et al..$^{[2]]}$ reported new evidence-based guidelines for the initial management of head trauma in the paediatric population and their guidelines to include criteria for selecting children for CT scans, in-hospital observation or early discharge, and suggestions for monitoring routines and discharge advice for children and guardians. This guideline separate mild head trauma patients into high-, medium- and low-risk categories, favouring observation for mild, low-risk patients as an attempt to reduce CT scans in children.

The limitation of our study is the retrospective nature and a small number of patients. In addition, there was a statistical study for the comparison of our outcomes.

\section{Conclusion}

Children have unique anatomic and physiologic properties, and head trauma is an important clinical condition in children. It should always be managed seriously and appropriate treatment methods should be applied.

Ethics Committee Approval: Approved by the local ethics committee.

\section{Peer-review: Internally peer-reviewed.}

Authorship Contributions: Concept: S.Y., A.K.; Design: S.Y.; Supervision: M.O.D.; Materials: S.Y.; Data: A.K.; Analysis: S.Y.; Literature search: S.Y., A.K.; Writing: A.K.; Critical revision: M.O.D. 
Conflict of Interest: None declared.

Financial Disclosure: The authors declared that this study has received no financial support.

\section{REFERENCES}

1. Araki T, Yokota H, Morita A. Pediatric Traumatic Brain Injury: Characteristic Features, Diagnosis, and Management. Neurol Med Chir (Tokyo) 2017;57:82-93. [CrossRef]

2. Dubey V, Nau E, Sycip M. Altered Mental Status in Children After Traumatic Brain Injury. Pediatr Ann 2019;48:e192-6. [CrossRef]

3. Lindholm EB, D'Cruz R, Fajardo R, Meckmongkol T, Ciullo S, Grewal $\mathrm{H}$, et al. Admission of Pediatric Concussion Injury Patients: Is It Necessary? J Surg Res 2019;244:107-10. [CrossRef]

4. Rotter J,Kamat D.Concussion in Children.Pediatr Ann 2019;48:e182-5.

5. Duhaime AC, Christian CW, Rorke LB, Zimmerman RA. Nonaccidental head injury in infants--the "shaken-baby syndrome". N Engl J Med 1998;338:1822-9. [CrossRef]

6. Hahn YS, McLone DG. Risk factors in the outcome of children with minor head injury. Pediatr Neurosurg 1993;19:135-42 [CrossRef]

7. Greenberg JK, Jeffe DB, Carpenter CR, Yan Y, Pineda JA, Lumba-Brown A, et al. North American survey on the post-neuroimaging management of children with mild head injurie J Neurosurg Pediatr 2018;23:227-35

8. Binder H, Majdan M, Tiefenboeck TM, Fochtmann A, Michel M, Hajdu $\mathrm{S}$, et al. Management and outcome of traumatic epidural hematoma in 41 infants and children from a single center. Orthop Traumatol Surg Res 2016t;102:769-74 [CrossRef]

9. Rumalla K, Smith KA, Letchuman V, Gandham M, Kombathula R, Arnold PM. Nationwide incidence and risk factors for posttraumatic seizures in children with traumatic brain injury. J Neurosurg Pediatr 2018;22:684-93 [CrossRef]

10. Zhang F, Huang L, Singichetti B, Li H, Sullivan L, Yang JG. Sex and age differences in hospitalised paediatric traumatic brain injuries. Pediatr Int.
2019 Jul 9. doi: 10.1111/ped.13946. [Epub ahead of pript]. [CrossRef]

11. Langlois JA, Rutland-Brown W, Thomas KE. Traumatic Brain Injury in the United States: Emergency Department Visits, Hospitalizations and Deaths. Atlanta: Centers for Disease Control and Prevention; 2004.

12. Luerssen TG, Klauber MR, Marshall LF. Outcome from head injury related to patient's age. A longitudinal prospective study of adult and pediatric head injury. J Neurosurg 1988;68:409-16 [CrossRef]

13. Smith A, Gruskin K, Monuteaux MC, Stack AM, Sundberg M, Yim R, et al. Reducing the cranial CT rate for pediatric minor head trauma at three community hospitals. Pediatr Qual Saf 2019;4:e14. [CrossRef]

14. Weber CD, Lefering R, Weber MS, Bier G, Knobe M, Pishnamaz M, et al. Predictors for pediatric blunt cerebrovascular injury (BCVI): An international multicenter analysis World J Surg 2019;43:2337-47.

15. Champagne PO, He KX, Mercier C, Weil AG, Crevier L. Conservative Management of Large Traumatic Supratentorial Epidural Hematoma in the Pediatric Population. Pediatr Neurosurg 2017;52:168-72. [CrossRef]

16. Faheem M, Jaiswal M, Ojha BK, Chandra A, Singh SK, Srivastava C. Traumatic Pediatric Extradural Hematoma: An Institutional Study of 228 Patients in Tertiary Care Center. Pediatr Neurosurg 2019;54:237-44 [CrossRef]

17. Gekat W, Binder S, Wetzel C, Rothschild MA, Banaschak S. SDH and $\mathrm{EDH}$ in children up to 18 years of age-a clinical collective in the view of forensic considerations. Int J Legal Med 2018;132:1719-22 [CrossRef]

18. Nguyen VN, Wallace D, Ajmera S, Akinduro O, Smith LJ, Giles K, et al. Management of Subdural Hematohygromas in Abusive Head Trauma. Neurosurgery 2020;86:281- [ [CrossRef]

19. Öğrenci A, Ekşi MŞ, Koban O, Karakuş M. Spontaneous rapid resolution of acute subdural hematoma in children. Childs Nerv Syst 2015;31:2239-43. [CrossRef]

20. Wright JN. CNS Injuries in abusive head trauma. AJR Am J Roentgenol 2017;208:991-1001 [CrossRef]

21. Astrand R, Rosenlund C, Undén J; Scandinavian Neurotrauma Committee (SNC). Scandinavian guidelines for initial management of minor and moderate head trauma in children. BMC Med 2016;14:33. [CrossRef]

\section{ORIJINAL ÇALIŞMA - ÖZET}

\section{Pediyatrik kafa travmaları: Farklı bir bakış açısı \\ Dr. Soner Yaşar, Dr. Alparslan Kırık, Dr. Mehmet Ozan Durmaz}

Sağlık Bilimleri Üniversitesi, Gülhane Tıp Fakültesi, Beyin ve Sinir Cerrahisi Anabilim Dalı, Ankara

AMAÇ: Pediyatrik kafa travmaları çalışmamızı sunmak ve sonuçlarımızı güncel literatürle tartışmaktır.

GEREÇ VE YÖNTEM: 2010 ve 2019 yılları arasında kliniğimizde kafa travması nedeniyle tedavi gören çocukların verileri geriye dönük olarak incelendi. Başvuru sırasındaki klinik durumu, radyolojik bulgular, tedavi yöntemleri ve sonuçları analiz edildi.

BULGULAR: Doksan çocuk kafa travması nedeniyle tedavi edildi, bunların 60'ı erkek, 30'u kız idi. Yaş ortalaması 6.6 idi. Elli beş hastada lineer kafatası kırı̆̆ı, 15 hastada epidural hematom görüldü. Yirmi hastaya cerrahi tedavi uygulandı, 70 hastaya konservatif tedavi uygulandı. Çalışmamızda hiçbir hasta kaybedilmedi, üç hastaya taburcu olduktan sonra nörolojik defisit nedeniyle fizik tedavi ve rehabilitasyon uygulandı.

TARTIŞMA: Çocuklar kafa travmasına daha erişkinlere göre yatkındır, ancak mortalite yetişkinlerden daha azdır. Konservatif tedavi ilk hedef olmalı, ancak önemli boyutlarda hematomlu ve kötüleşen nörolojik tablosu olan çocuklar için cerrahi tedavi düşünülmelidir.

Anahtar sözcükler: Cerrahi; çocuk; kafa travması; sonuç.

Ulus Travma Acil Cerrahi Derg 2020;26(5):765-768 doi: I0.14744/tjtes.2020.24287 